dabas un vides apstākḷiem. Mūsu kopīgais uzdevums ir atrast Latvijas tautu vienojošos elementus un izmantot daudzveidību attīstībai. Monogrāfijas autori cer, ka visaptveroša Latvijas iepazī̌šana, lasot šo grāmatu, dos jaunas idejas katras Latvijas vietas un kopumā visas valsts attīstībai, kā arī sekmēs mācību grāmatu izveidi, pieejamību korektai, precīzai un jaunai informācijai par mūsu valsti.

Monogrāfijas vērtība ir arī tanī apstāklī, ka daudzu pētījumu rezultāti plašākai Latvijas sabiedrībai līdz šim nebija pieejami, jo tie vairumā gadījumu tika publicēti starptautiskos zinātniskos žurnālos. Grāmata ir bagātīgi ilustrēta ar kartogrāfisko materiālu un fotoattēliem, kas ne tikai l̦auj vieglāk uztvert tekstu, bet arī sniedz jaunas zināšanas par valsti un tās reǵioniem. Izdodot šo grāmatu latviešu valodā, jaunākā zinātniskā informācija ǵeogrāfijā, ǵeoloǵijā, vides zinātnē un ekologijā ir pieejama Latvijas iedzīvotājiem, ieskaitot skolotājus, studentus un valsts pārvaldes darbiniekus.

Monogrāfijas sagatavošanā iesaistīti Latvijas vadošie ǵeogrāfijas, vides un ekoloǵijas speciālisti. Autoru kolektīvu veido 61 zinātnieks. Neatsveramu ieguldījumu monogrāfijas tapšanā līdzās tās autoriem devuši redaktore Ieva Zarāne, korektore Gita Bērzina, dizainere-maketētāja Ieva Tiltiṇa, vāka autore Baiba Lazdiṇa, kartogrāfi Ivo Vinogradovs un Jānis Ivanovs un daudzie fotogrāfiju autori.

Monogrāfija ir dāvana valsts simtgadei. Tās tapšanu finansiāli atbalstīja Latvijas Vides aizsardzības fonds un Latvijas Universitāte, un, pateicoties šim atbalstam, tā ir nonākusi visās Latvijas bibliotēkās un lielākajās skolās.

\title{
ROMU, KRIEVU UN LATVIEŠU DZĪVESSTĀSTI LATVIJĀ
}

Inese Š̄upule, $D r . s c . s o c$.

Dažādu etnisko grupu dzīvesstāstu salīdzināšana un vēlme uzzināt ne tikai latviešu, bet arī Latvijas krievu un romu dzīvesstāstus raksturo jaunu nodaḷu Latvijas dzìvesstāstu pētniecībā. Pieredzējušie LU Filozofijas un sociologijas institūta mutvārdu vēstures pētnieki atklāj jaunas iespējas dzīvesstāstu interpretēšanā un izpratnē, jo atklājas etniskās piederības ietekme uz dzīvesstāstu veidolu un saturu, kā arī etniskās piederības aspekts stāstītāja un intervētāja mijiedarbībā. Kā grāmatas Piederēt un atšksirties. Romu, krievu un latviešu dzīvesstāsti Latvijā ([2017] Rīga : Dzīvesstāsts) ievadā norāda izdevuma zinātniskā redaktore Vieda Skultāne, tā ir "dinamiska saspēle starp pašu stāstītāju, intervētāju - klausītāju un stāstāmo vēstījumu", jo noteiktā situācijā dzīvesstāsti tiek nemit̄̄gi radīti no jauna.

Dzīvesstāstu interpretācijā grāmatas autori aplūko dažādas tēmas - tradīcijas, etnisko kultūru saskarsmi, kolektīvo atmiņu, pašrefleksiju, brīvību. Pētnieku analīzi veicina vairāku filozofu un sociālo zinātņu pārstāvju atziņas, bet īpaši jāizcel trīs autoru ietekme. Alisdaira Makintaira izpratne par tradīcijām dzīvesstāstu analīzē autoriem palīdz izcelt stāstītāju pārdomas par tradīcijām un tradīciju nozīmi ${ }^{1}$. Savukārt Čārlza Teilora rakstītais ${ }^{2}$ iedrošina saskatīit stāstītāja situatīvo izpratni par labo un dz̄ivē nozīmīgo, ko nosaka kultūrā sakṇotas vērtības. Jesajas Berlina atziņas par brīvības problemātiku un nošķ̄īumi "brīvība no kaut kā" un "brīvība kaut kam" l̦auj atklāt brīvības nozīmi un izpratni dzīvesstāstos.

1 Sal. MacIntyre, A. (1981) After Virtue: A Study in Moral Theory. Indiana : University of Notre Dame Press.

2 Taylor, C. (1989) Sources of the Self: The Making of the Modern Identity. Cambridge : Harvard University Press.

3 Berlins, J. (2000) Četras esejas par brīvību. Rìga : Sprīdītis. 
Monogrāfija sagatavota Latvijas Zinātnes padomes pētījumu projektā Nr. 370/2012 Etniskā un naratīvā dažādība dzīvesstāstu konstrukcijās Latvijā. Pētījuma gaitā veiktas vairāk nekā 100 romu un krievu dzīvesstāstu intervijas, kas organizētas ne tikai Rīgā, bet arī Talsos, Kuldīgā, Jelgavā, Kandavā, Ventspilī, Dundagā, Rūjienā, Viḷakā, Tūjā un Tomē. Analīzē izmantoti arī latviešu, krievu un romu dzīvesstāsti, kas ierakstīti agrāk un pieejami Nacionālās mutvārdu vēstures krājumā.

Atzīstami vērtējama ir grāmatai raksturīgā uzmanība dzīvesstāstu interpretācijā, īpaši attiecībā uz vispārinājumiem par kādas etniskās grupas dzīvesstāstiem. Būtiska ir arī grāmatā paustā atziņa, ka, iespējams, turpmākajā analīzē nepieciešams lielāku vērību pievērst nevis atškirīgajam, bet tieši kopīgajam individuālajos dažādu etnisko grupu pārstāvju dzīvesstāstos, tādējādi mazinot Latvijas sabiedrības sašķeltîbu.

Grāmatas pirmā nodaḷa, kuras autore arī ir V. Skultāne, veltīta tam, lai konceptuāli apzinātu tradīcijas, pašizpratni un vērtības dzīvesstāstos, un ievada pārējo autoru analīzi. Māras Zirnītes analīze par etnisko kultūru saskarsmi dz̄ivesstāstos atklāj, kā notiek dažādu etnisko kultūru mijiedarbe Latvijā, kur būtiska ir gan indivīda pieredze un atvērtīiba, gan lokalitāte, gan arī uz konkrētu atminu kopienu balstīta izpratne par vēstures notikumiem vai to noklusēšana.

Kolektīvās atmiņas jautājumiem Latvijas krievu dzīvesstāstos padziḷināti pievēršas Kaspars Zellis. Analīzes sākumā autors problematizē jautājumu par paralēlām atmiṇu kopienām mūsu valstī, kas konstruētas, uzsvaru liekot uz šo kopienu atšķirībām, bet neievērojot kopīgo. Autors parāda, ka Latvijas politiskās atmiņas etnocentrisms, Krievijas tautiešu politikas ietekme, masu kultūras patēringa prakses ir daži no iemesliem, kuru dēḷ Latvijas krievu dzīvesstāstos ir vērojama nespēja sevi piesaistît latviešu kolektīvajai atminnai.

Nadeždas Pazuhinas analīzē uzmanība pievērsta tam, kā Latvijas krievu dzīvesstāstos atklājas "nozīmīgo citu" ietekme un normatīva uzvedība un audzināšana, kur "nozīmīgo citu" autoritāte bieži vien tiek saistīta ar normalizējošo diskursu un attiecināta uz varas institūciju atbildību par notiekošo. Vienlaikus tiek atklātas arī indivīdu prakses, dzīves taktikas varas kontroles apiešanā, kā arī ironiska attieksme pret PSRS dominējošo ideologiju.

Edmunds Šūpulis Latvijas romu dzīvesstāstos analizē romu priekšstatus par pagātni un etnisko identitāti un atklāj, ka romu dzīvesstāstos īpašu vietu ieņem kolektīvā atmiņa par dzīvi nacisma un padomju režīmā, kas pauž traǵisko genocīda pieredzi, kam seko relatīva drošība un pārticība sociālistiskās saimniecības apstākḷıs. Viens no būtiskiem autora secinājumiem par romu dzīvesstāstiem skar atmiñas veidošanās īpatnības romu kopienā. Kamēr latviešu vidū dzīvesstāsti veidojas lielā mērā ap vēstures notikumiem kā būtiskiem mezgla punktiem (paralēli notikumiem personiskajā dzìvē), romu vidū pašizpratne tiek konstruēta saistībā ar romu statusu sabiedrībā un attiecībās ar citām etniskajām grupām.

Dagmāras Beitneres-Le Gallas analīzes uzmanības centrā ir piederības meklējumi krievu dzīvesstāstos. Analīze atklāj dažādas prakses un identitātes konstruēšanas piemērus, kas ḷauj izprast Latvijas krievu un cilvēku no etniski jauktām ǵimenēm heterogēno kopienu un atškirīgos dzīvesstāstus. Autore pievēršas arī sāpīgajai klusuma zonai dzīvesstāstos, kur neizstāstītie ǵimenes locekḷu likteṇi traumējoši ielaužas stāstītāju dzīvesstāstos.

Maruta Pranka dzīvesstāstus aplūko kā vēstījumus, kuros atklājas dz̄ives gājumā piedzīvotie zaudējumi un ieguvumi. Aplūkotajos dzīvesstāstos galvenie pārmaiṇu nesēji ir bijuši Otrais pasaules karš un 90. gadu politiskās un sekojošās ekonomiskās un sociālās izmaiņas.

Ieva Garda-Rozenberga un Maija Krūmiņa dz̄ivesstāstos analizē brīvības nozīmi un secina: stāstos par brīvības ierobežojumiem vērojams, ka priekšplānā izvirzās nepieciešamība pēc uzticības pašam sev, līdzcilvēkiem un nozīmīgām morālajām vērtībām. Saskaroties ar brīvības ierobežojumiem, indivīdi ir spiesti pielāgoties, tomēr cenšas saglabāt savu iekšējo brīvību.

Nobeigumā jāuzsver, ka grāmatā apkopotā dažādu autoru analīze un pieeja dzìvesstāstu pētniecībai piedāvā nozīmīgu platformu diskusijām par piederību un atškirirībām etnisko grupu kolektīvajā atmin̄ā. Turpmākai pētniecībai tiek izvirzīti būtiski jautājumi, vai Latvijā pastāv tikai viena Latvijas krievu atmiņu kopiena vai arī tā drīzāk būtu jāuzlūko kā dažādu mediju telpu vispārinājuma produkts. 